\title{
Insulin-like Growth Factor Binding Protein-3 Induces Apoptosis in MCF7 Breast Cancer Cells
}

\author{
Tara Nickerson, Hung Huynh, and Michael Pollak ${ }^{1}$ \\ Lady Davis Research Institute of the J ewish General Hospital and Departments of Oncology and Medicine, \\ McGill University, Montreal, Quebec, Canada H3T 1E2
}

Insulin-like growth factors (IGFs) are known to have potent antiapoptotic activity. The antiestrogen ICI 182,780 (ICI) is a potent inhibitor of MCF 7 human breast cancer cell growth and has recently been reported to act as an antiproliferative agent in part via upregulation of expression of insulin-like growth factor binding proteins (IGF BPs) -3 and -5 , which attenuate the bioactivity of IGFs in many experimental systems. We show here that ICI and IGFBP-3 induce apoptosis in MCF 7 cells. Treatment of MCF 7 cells with $10 \mathrm{nM} \mathrm{ICI}$ or $36 \mathrm{nM}$ recombinant human I GF BP3 for 72 hours increased apoptosis $\sim 3.5$-fold relative to control as quantitated by a cell death ELISA which measures DNA fragmentation. Long $R^{3}$ I GF-I, an IGFI analogue with greatly reduced affinity for IGFBPs yet similar affinity for IGF-I receptors, was a more potent inhibitor of IGF BP-3-induced and ICI-induced apoptosis than IGF-I. These results suggest that IGFBP-3 enhances apoptosis by reducing bioavailability of ligands for the IGF-I receptor and suggest that modulation of IGF BP-3 expression by ICI contributes to apoptosis induced by this compound. More generally, the data suggest that IGFBPs are regulators of apoptosis.

Apoptosis is a physiological phenomenon involved in morphogenesis and tissue renewal (1). Transformed cells have been shown to have defects in activation of the apoptotic pathway, suggesting that derangements of apoptosis are involved in the pathophysiology of cancer. Many antineoplastic compounds induce tumor regression through their ability to activate apoptotic pathways $(2,3)$. Recent studies $((4,5)$ reviewed in $(6))$ have demonstrated that activation of the insulin-like growth factor I (IGF-I) receptor by IGF-I or IGF-II pro-

\footnotetext{
${ }^{1}$ Corresponding author. Lady Davis Research Institute, 3755 Cote Ste Catherine Road, Montreal, Quebec, Canada H 3T 1E2. Fax: (514) 340-7502. E-mail: md49@musica.mcgill.ca.
}

tects cells from apoptosis, and have implicated the serine-threonine kinase Akt as a key downstream regulator of the antiapoptotic effect of IGF-IR agonists (7). However, little attention has been given to date to the role of insulin-like growth factor binding proteins (IGFBPs) $(8,9)$ in regulating apoptosis.

The pure antiestrogen $\mathrm{ICl} 182,780(\mathrm{ICl})$ is a potent inhibitor of breast cancer cell growth (10). We have previously reported that the antiproliferative effects of $\mathrm{ICl}$ on MCF 7 cells are associated with increased expression and secretion of IGFBP-3 (11).

\section{MATERIALS AND METHODS}

Cell culture and growth experiments. MCF 7 cells are routinely maintained in $10 \%$ fetal calf serum (FCS) alpha modified minimal essential media $(\alpha$ MEM) supplemented with $5 \mu \mathrm{g} / \mathrm{ml}$ insulin. They were plated in $5 \%$ FCS phenol red free (PF) $\alpha$ MEM at a density of 25,000 cells/well in 24-well plates. Following attachment for 24 hours, cells were washed twice in $0.5 \% \mathrm{FCS}$ PF $-\alpha$ MEM and incubated in this media for 3 hours. Exposure to compounds under study was for 72 hours in $0.5 \% \mathrm{FCS}$ PF - $\alpha$ MEM. Proliferation of cells was quantitated by $\left[{ }^{3} \mathrm{H}\right]$-thymidine incorporation as previously described (12).

Quantitation of apoptosis. Apoptotic cell death was measured using a cell death ELISA (Boehringer Mannheim) which measures cytoplasmic histone-bound DNA generated during apoptotic DNA fragmentation and not free histone or DNA that could be released during nonapoptotic cell death. This method has been shown to be reliable for quantitation of apoptotic cell death in MCF 7 cells $(13,14)$. MCF 7 cells plated at a density of 25,000 cells/well and treated for 72 hours exactly as described for growth experiments were harvested by scraping in cold phosphate buffered saline. Parallel plates treated identically were used for thymidine incorporation and for determination of cell number. Cytoplasmic cell extracts were prepared according to the manufacturer's protocol and were equalized on the basis of cell number. Samples from triplicate wells were run in duplicate on the ELISA.

\section{RESULTS AND DISCUSSION}

It has previously been shown that the antiestrogen ICI 182,780 induces apoptosis in MCF 7 cells as demonstrated by cleavage of DNA to 300 and $50 \mathrm{kbp}$ fragments (15), although there is controversy surrounding 
A

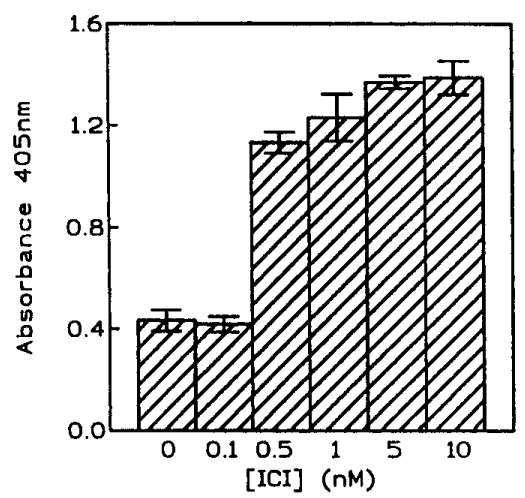

B

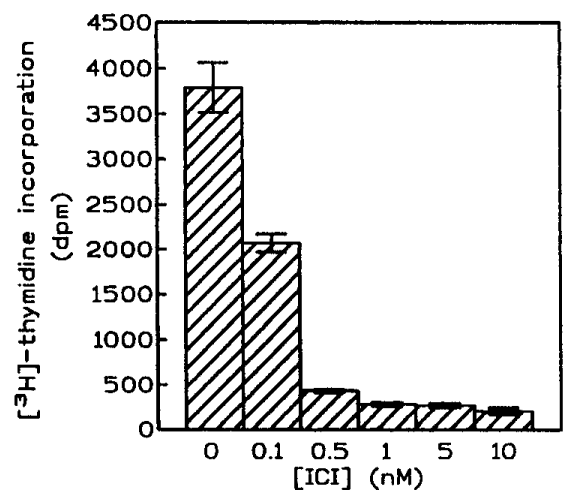

C
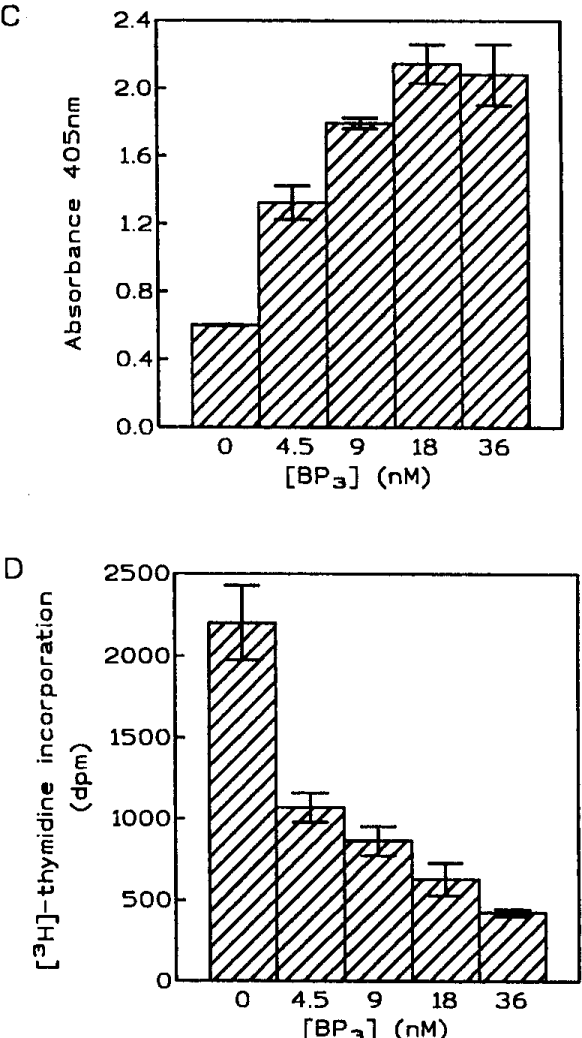

FIG. 1. Induction of apoptosis in MCF 7 cells in response to the antiestrogen ICI 182,780 and IGFBP-3. MCF 7 cells plated at a density of 25,000 cells/well were treated for 72 hours in $0.5 \%$ FCS. Apoptosis induced by various doses of ICI (A) and rhI GFBP-3 (C) was quantitated by cell death ELISA where absorbance at $405 \mathrm{~nm}$ is a direct measure of DNA fragmentation. Plates treated in parallel were used to measure $\left[{ }^{3} \mathrm{H}\right]$-thymidine incorporation (B and D). All experiments were repeated at least three times. The results from one representative experiment are shown expressed as mean \pm SE of triplicate wells.

the use of DNA laddering to detect apoptosis in MCF 7 cells in response to antiestrogens $(16,17)$. The cell death ELISA used to quantitate apoptosis in our experiments has been shown to detect apoptosis in MCF 7 cells in response to the antiestrogens tamoxifen and toremifene (13) as well as other agents (14). Our results support the view that antiestrogens induce apoptosis in MCF 7 cells. We observed a dose-dependent increase in apoptosis following exposure of MCF 7 cells to I CI for 72 hours (Figure 1A). A 3.2-fold increase in apoptosis was observed in cells treated with 10nM $\mathrm{ICl}$ compared to vehicle-treated controls. This is correlated with the well known potent inhibitory effects of $\mathrm{ICI}$ on MCF 7 DNA synthesis (Figure 1B). Under the same experimental conditions, treatment of MCF 7 cells with recombinant human IGFBP-3 (rhIGFBP-3) for 72 hours increased apoptotic cell death in a dosedependent manner (Figure $1 \mathrm{C}$ ) and inhibited [ $\left.\mathrm{H}^{3}\right]$-thymidine incorporation (Figure 1D). Apoptosis increased 3.5-fold in the presence of $36 \mathrm{nM}$ rhIGFBP-3 relative to control.

We have previously shown that the potent inhibitory effects of ICI on MCF 7 cell growth are associated with increased secretion of IGFBP-3 by the cells (11). It is therefore possible that induction of apoptosis by $\mathrm{ICI}$ may be related to secretion of IGFBP-3. In order to determine if ICl-induced IGFBP accumulation is functionally related to its apoptosis-inducing actions, we carried out experiments with long R ${ }^{3}$ IGF-I (Gropep, Adelaide, Australia), an IGF-I analogue with greatly reduced affinity for IGF binding proteins, yet similar affinity for IGF -I receptors (18). Experiments were carried out in the presence of $0.5 \% \mathrm{FCS}$, as preliminary studies showed that this condition was associated with a level of apoptosis in the detection range of our assay. As shown in figure 2, baseline levels of apoptosis in the absence of either IGF-I or long $\mathrm{R}^{3}$ IGF-I are more than doubled in the presence of $10 \mathrm{nM} \mathrm{ICl}$. The relatively Iow levels of apoptosis seen in the absence of $\mathrm{ICl}$ are minimally effected by addition of either IGF-I or long $\mathrm{R}^{3}$ IGF-I to the media. Autocrine expression of IGF-I and IGF-II by MCF 7 cells could not be detected in this system (data not shown). Furthermore, the similar results obtained with IGF-I or long R $^{3}$ IGF-I under these conditions indicate that the IGFBPs present in the media (from serum or autocrine production) have a negli- 
gible effect on apoptosis in our experimental system in the absence of the antiestrogen.

On the other hand, long $\mathrm{R}^{3}$ IGF-I was a more potent inhibitor of $\mathrm{ICl}$-induced apoptosis than IGF-I. $1.4 \mathrm{nM}$ IGF-I reduced the apoptosis induced by $10 \mathrm{nM} \mathrm{ICI}$ by 40\% (Mann Whitney $U$-test, $p<0.05$ ), while the same concentration of long $\mathrm{R}^{3}$ IGF-I completely abolished $\mathrm{ICI}$-induced apoptosis (Figure 2). The antiapoptotic activity of IGF -I in our system extends prior work $(4,19)$ showing attenuation of apoptosis induced by agents such as etoposide and tumor necrosis factor to antiestrogen-induced apoptosis. Furthermore, the differences between the antiapoptotic effect of IGF-I and long $\mathrm{R}^{3}$ IGF-I in our experimental system suggests that the recently described induction of IGFBP-3 expression by ICI (11) contributes to the apoptotic action of the antiestrogen. The data are consistent with the view that the apoptotic action of $\mathrm{ICl}$ is related to competition between ICI-induced IGFBP-3 and the IGFIR for IGF-I.

In co-incubation experiments, both $36 \mathrm{nM}$ rhI GFBP3 and $10 \mathrm{nM} \mathrm{ICI}$ significantly increased the levels of apoptosis seen in the presence of 1.4 nM IGF -I (Mann Whitney $\mathrm{U}$-test, $\mathrm{p}<0.01$ ) (Figure 3 ). However, in the presence of $1.4 \mathrm{nM}$ long $\mathrm{R}^{3} \mathrm{IGF}-\mathrm{I}, \mathrm{ICl}$ and rhIGFBP-3 had no influence on apoptosis. These results suggest a functional role for IGFBPs in the induction of apoptosis by $\mathrm{ICI}$.

The IGF-IR plays a key role in regulating programmed cell death and has been suggested to promote cell survival by directly inhibiting apoptosis $(4,5)$. We previously reported that $\mathrm{ICI}$ downregulates IGF-IR

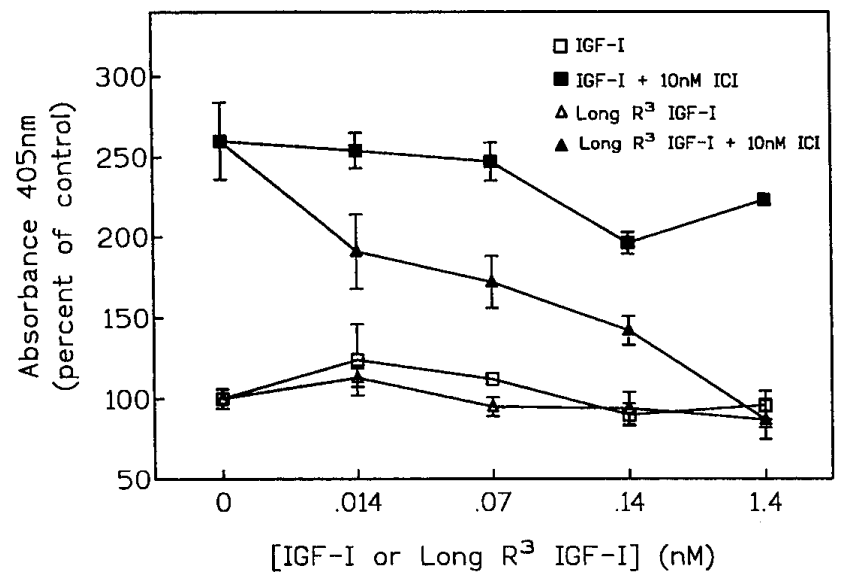

FIG. 2. Effects of IGF-I and Long $R^{3} I G F-I$ on apoptosis induced by $\mathrm{ICl}$. MCF 7 cells were plated as described in the legend to figure 1 and treated for 72 hours in $0.5 \%$ FCS with various doses of IGF-I (open squares) or long $\mathrm{R}^{3}$ IGF-I (open triangles) alone or in the presence of $10 \mathrm{nM} \mathrm{ICl}$ (filled squares and filled triangles, respectively). Cytoplasmic extracts equalized on the basis of cell number were run on the ELISA as described under Materials and Methods. The experiment was repeated three times and the results from one experiment are shown expressed as mean $\pm \mathrm{SE}$.

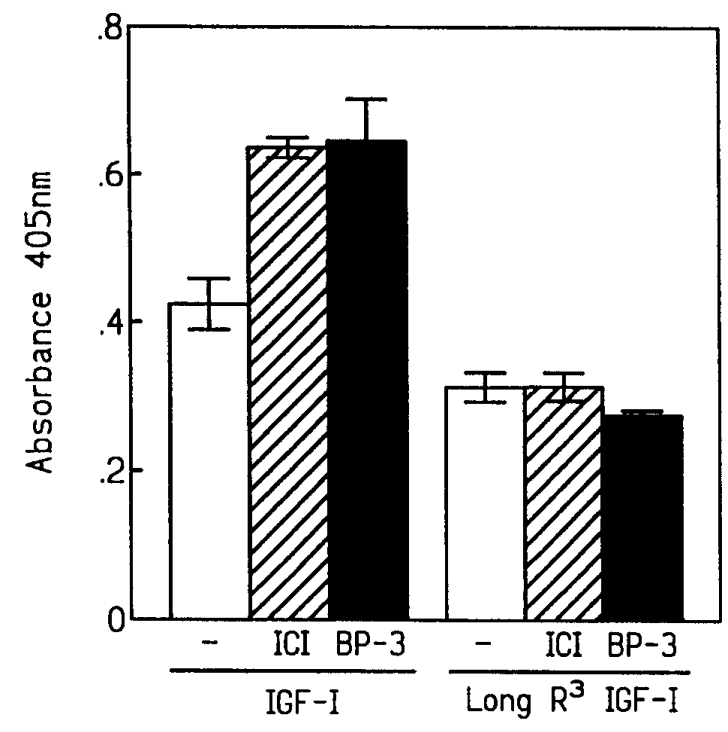

FIG. 3. Effects of IGF-I and Long $R^{3} I G F-I$ on protecting MCF 7 cells from apoptosis induced by $\mathrm{ICl}$ and IGFBP-3. Cells plated at 25,000 cells/well were cultured for 72 hours in $0.5 \%$ FCS with or without $10 \mathrm{nM} \mathrm{ICl}$ or $36 \mathrm{nM}$ rhlGFBP-3 in the presence of either 1.4 nM IGF-I or long R ${ }^{3}$ IGF-I. Cytoplasmic extracts from cells were run on the cell death ELISA and $A_{405}$ was measured. Data are expressed as mean \pm SE from triplicate wells.

number in MCF 7 cells (20). Although this raises the possibility that induction of apoptosis in MCF 7 cells by ICI may be related in part to reduction of IGF-IR levels, the magnitude of changes in IGFBP-3 and IGFBP-5 expression in response to $I C I$ are much greater than $\mathrm{ICl}$-induced changes in IGF-IR expression $(11,21)$.

Recent evidence has emerged that IGFBP-3 has direct growth inhibitory effects that are independent of its capacity to bind IGF-I, which are mediated by a putative IGF BP-3 receptor (22). In view of these observations, it is possible that IGFBP-3 can influence apoptotic pathways through mechanisms other than modulation of IGF bioactivity. However, the fact that rhI GF BP-3 attenuates the antiapoptotic effects of I GF I but not of long $R^{3}$ IGF-I strongly suggests that in our experimental system IGFBP-3 enhances apoptosis indirectly by reducing binding of IGFs to the IGF-IR.

The observation that induction of apoptosis in the rat mammary gland during post-lactational involution is correlated with greatly increased IGFBP production (23) suggests that I GF BPs may be important physiological regulators of apoptosis in the breast. The finding that I GFBP-3 is upregulated by p53 in EBI col on carcinoma cells (24) has led to speculation that IGFBP-3 regulates apoptosis by reduction of IGF bioactivity (25). Our data provide the first direct demonstration that I GF BP-3 induces apoptosis in MCF 7 cells, and suggest that the apoptotic action of $\mathrm{ICI}$ is mediated, at least in part, by ICI-induced IGFBP expression. Our results are consistent with the hypothesis that in general, IGFBPs 
regulate apoptosis by modulating IGF bioactivity. I GF BP-3 has recently been reported to mediate TGF $\beta$ induced apoptosis in PC-3 prostate carcinoma cells (26). Our observations that I GFBPs contribute to antiestrogen-induced apoptosis in breast cancer cells provide further evidence for a role of IGFBPs as regulators of apoptosis.

\section{ACKNOWLEDGMENTS}

This work was supported in part by a grant from the National Cancer Institute of Canada to MP. We thank Dr. Alan Wakeling for his generous gift of $\mathrm{ICl}$ 182,780 and Celtrix Pharmaceuticals (Santa Clara, CA) for providing human recombinant IGFBP-3.

\section{REFERENCES}

1. White, E. (1996) Genes Devel opment 10, 1- 15.

2. Fisher, D. E. (1994) Cell 78, 539-542.

3. Welsh, J. (1994) Biochem. Cell Biol. 72, 537-545.

4. Sell, C., Baserga, R., and Rubin, R. (1995) Cancer Res. 55, 303306.

5. Resnicoff, M., Abraham, D., Yutanawiboonchai, W., Rotman, H. L., Kajstura, J ., Rubin, R., Zoltick, P., and Baserga, R. (1995) Cancer Res. 55, 2463-2469.

6. Baserga, R. (1995) Cancer Res. 55, 249- 252.

7. Gloth, F. M., Gloth, T., and J ordan, D. (1995) J . Amer. Geriatrics Soc. 43, 822-828.

8. J ones, J . I., and Clemmons, D. R. (1995) Endocr. Rev. 16, 3- 34.

9. Oh, Y., Nagalla, S., Yamanaka, Y., Kim, H. S., Wilson, E., and Rosenfeld, R. G. (1996) J . Biol. Chem. 271, 30322- 30325.
10. Wakeling, A. E., Dukes, M., and Bowler, J . (1991) Cancer Res. 51, 3867-3873.

11. Huynh, H. T., Yang, X. F., and Pollak, M. (1996) J . Biol. Chem. 271, 1016- 1021.

12. Pratt, S. E., and Pollak, M. (1993) Cancer Res. 53, 5193- 5198.

13. Wang, T. T., and Phang, J . M. (1995) Cancer Res. 55, 2487- 2489.

14. Mandal, M., and Kumar, R. (1996) Cell Growth Differ. 7, 311318.

15. Wilson, J . W., Wakeling, A. E., Morris, I. D., Hickman, J . A., and Dive, C. (1995) Int. J . Cancer 61, 502-508.

16. Kyprianou, N., English, H. F., Davidson, N. E., and I saacs, J . T. (1991) Cancer Res. 51, 162-166.

17. Warri, A. M., Huovinen, R. L., Laine, A. M., Martikainen, P. M., and Harkonen, P. L. (1993) J NCl 85, 1412- 1418.

18. Francis, G. L., Ross, M., Ballard, F.J ., Milner, S.J ., Senn, C., McNeil, K. A., Wallace, J . C., King, R., and Wells, J. R. (1992) J . Mol. Endocrinol. 8, 213-223.

19. Wu, Y., Tewari, M., Cui, S., and Rubin, R. (1996) J . Cell. Physiol. 168, 499- 509.

20. Huynh, H. T., Nickerson, T., Pollak, M., and Yang, X. F. (1996) Clin. Cancer Res. 2, 2037- 2042.

21. Huynh, H.T., Yang, X.F., and Pollak, M. (1996) Cell Growth Differ. 7, 1501- 1506.

22. Oh, Y., Muller, H. L., Lamson, G., and Rosenfeld, R. G. (1993) J. Biol. Chem. 268, 14964- 14971.

23. Tonner, E., Quarrie, L., Travers, M., Barber, M., Logan, A., Wilde, C., and Flint, D. (1995) Progress in Growth Factor Re search 6, 409-414. [Abstract]

24. Buckbinder, L., Talbott, R., Velasco-Miguel, S., Takenaka, I., Faha, B., Seizinger, B. R., and Kley, N. (1995) Nature 377, 646649.

25. van der Wielen, R. P., Lowik, M. R., van den Berg, H., de Groot, L. C., Haller, J ., Moreiras, O., and van Staveren, W. A. (1995) Lancet 346, 207- 210.

26. Rajah, R., Valentinis, B., and Cohen, P. (1997) J . Biol. Chem. 272, 12181- 12188. 